\title{
The Barriers to the Use of ICT in Teaching in Saudi Arabia: A Review of Literature
}

\author{
Ensaf Al Mulhim \\ Plymouth University, Drake Circus, Plymouth, PL1 3EU, United Kingdom \\ *Corresponding Author: e_almulhim@hotmail.com
}

Copyright (c) 2014 Horizon Research Publishing All rights reserved.

\begin{abstract}
The paper reports some of the reasons behind the low use of Information and Communication Technology (ICT) by teachers. The paper has reviewed a number or studies from different parts of the world and paid greater attention to Saudi Arabia. The literature reveals a number of factors that hinder teachers' use of ICT. This paper will focus on lack of access to technology, lack of training and lack of time.
\end{abstract}

Keywords Saudi Arabia, ICT, Barriers, Educational Technology, Teachers, Lack of Access, Lack of Time, Lack of Training, Literature Review

\section{Introduction}

Barriers to ICT inclusion in education could be either teacher or school related. The literature states a number of obstacles at teacher and school level [1-6]. However, the most important and common teacher level barriers are: teachers' attitude towards technology, teachers' resistance to change, lack of time, teachers' lack of confidence in using technology, and lack of knowledge and skills in using technology, while school level obstacles are: lack of access to technology, lack of effective training, lack of technical support, the high cost of hardware and software, and so on.

Indeed, facing just one disabler is sufficient to prevent a teacher from using ICT due to the close relationship among the barriers. According to Jones [2], each barrier to ICT use could influence a number of other barriers. He gives an example of how "teacher confidence" in using ICT is directly impacted by different disablers including the level of technology access, level of personal access to technology and the amount and quality of training available for teachers.

For the purpose of this paper, some of both school- and teacher-level barriers will be highlighted. More specifically, lack of access to technology, lack of effective training and lack of time will be discussed with special reference to Saudi literature.

\section{Barriers that Hinder Teachers from Using ICT in their Teaching}

\subsection{Lack of Access to ICT}

Inaccessibility or unavailability of ICT, a school-level barrier, has been identified as a key obstacle that impedes teachers from using it in teaching. Thus, this factor has interested an enormous number of researchers [7]. Shortage of resources includes different factors, such as lack of access to hardware and software, poor quality hardware and inappropriate software [2]. In its statistical analysis report, the National Center for Education Statistics in the United States of America found a positive correlation between the availability of ICT in the classroom and the likelihood of teachers assigning home work that required the use of ICT by students [8]. Alev [1] believes that offering plenty of resources can lure and persuade teachers to use them whilst teaching. According to Mumtaz [9] (p. 336), "Limited resources within schools are a great impediment to the take-up of ICT. Lack of computers and software in the classroom can seriously limit what teachers are able to do with ICT." In 2002, the British Department for Education and Skills launched the "Laptops for Teachers" initiative that aimed to provide laptops to selected teachers on long term loan [10]. This initiative's main goal was to increase teachers and headteachers access to computers. The evaluation of the first year of this initiative showed that since receiving their laptops, the teachers had become more likely to integrate ICT in their teaching and guide students' ICT use.

Furthermore, the teachers highlighted that they had become more confident when using ICT and they also became familiar with new software packages. In the 2003 report for Becta by Cox et al. called 'ICT and pedagogy: A review of the literature', it was emphasised that most teachers were less likely to buy their own ICT tools; instead, they would prefer to use the technological tools that were made available for them.

Moreover, about $70 \%$ of the respondents to Pelgrum's survey [11] reported 'Insufficient number of computers' as a 
great obstacle while $54 \%$ highlighted 'Insufficient copies of software' as a key obstacle to ICT integration.

In Saudi Arabia, integrating technology in schools is limited due to lack of hardware and unavailability of Internet access during the school day [5]. The majority of the teachers who participated in Al-Rashed's [12] research reported technology unavailability as one of the major obstacles and challenges that impede educational technology integration. The results also indicated that many schools in Saudi Arabia have only a small number of computers that are subsidised by the teachers' own subscriptions. Al-Showaye [13] wanted to assess computer and Internet facilities in intermediate and secondary schools in Saudi Arabia in order to investigate the extent of the current use of ICT, and to identify the barriers that hinder teachers from using it. For this purpose and others, he administered a survey of 143 teachers and 686 students from 29 public and private schools of both intermediate and secondary stages in Al-Qasseem region in Saudi Arabia. He also interviewed 10 teachers and 18 students drawn from the questionnaire sample. The analysis of these data demonstrated 16 barriers to ICT integration, including inadequate numbers of computers available for intermediate and secondary teachers. Al-Saif [14] added the lack of Arabic educational software to the barriers already cited. In a study that was carried out by Almaghlouth [3] and focused on Saudi secondary school science teachers' perceptions of the use of ICT tools to support teaching and learning, participants highlighted the lack of a suitable place for ICT integration such as a resources room and a laboratory fully equipped with the latest technologies. Oyaid [15] studied secondary students' perceptions of ICT and their usage of it inside and outside schools in Riyadh. The students who participated in her study reported that their teachers did not use technology frequently. Oyaid [15] explained that this result related to her finding that more than half of all students said that computer facilities in school were insufficient. Oyaid [15] also concluded that due to this shortcoming, Internet based activities were more likely to be carried out at home. Gady [16], moreover, found that crowded classrooms made it very difficult to equip the classrooms with any technology. Similarly, Alghamdi's [17] study, on the reality of computers in secondary schools that included 33 computer teachers in Altaif city, Saudi Arabia, emphasised the problem of lack of access to enough computers to meet the needs of a huge number of students in each classroom. Al Mulhim's [18] study that investigated why novice female primary teachers in Saudi Arabia do not use ICT in their teaching. She surveyed 135 teachers and interviewed 20 teachers from six cities in Saudi Arabia. The findings from the questionnaire revealed that $68.1 \%$ of the participants in addition to $55 \%$ of the interviewees selected lack of access to technology as a main barrier that prohibited them from using ICT.

\subsection{Lack of Training}

Improving any educational system significantly depends upon teachers' training and professional development [19]. The factor of lack of effective training is often mentioned in the literature as one of the most significant barriers to realising the full benefit of educational technology. According to Jones [2], benefiting from training is not easy, as the effectiveness of the training must be ensured. Jones' [2] study also found that time for training, including pedagogical training, ICT skills training and practice in ICT use should be considered of great importance. A study by Cox et al. [4] shows that teachers who had attended professional development in ICT still did not know how to integrate technology into their teaching; instead they had learnt how to turn a computer on and off and how to set up a printer.

McCarney [20] found that staff development based on pedagogy (how to use ICT to promote pupil learning) was perceived as highly effective, compared with training that placed greater emphasis on academic/content-related learning. Thus knowledge and understanding, such as understanding what a database is and when it can be used was more helpful than technical aspects such as developing word processing skills.

According to Jones [2], inappropriate training styles that lack pedagogical aspects are likely to be unsuccessful, so that high levels of ICT use by teachers are not achieved. A recent case study done by Unal and Ozturk [21] was interested in social studies teachers in Turkey and aimed to investigate the barriers to ICT integration into their classroom practices. The authors found that only 6 teachers out of a total of 18 reported that they had received in-service ICT training. These 6 teachers also stated that the ICT training that they received was ineffective due to the absence of the pedagogical aspects. Unal and Ozturk [21] (p. 942-943) therefore concluded that:

\section{"Another related problem is that the training given about ICT is mostly for general knowledge and skills. Interviewed teachers state that the in-service training they received did not include generally ICT- based methods and approaches for teaching social studies. Within the scope of in-service training only general skills of using ICT equipment were emphasized, without relating them to teaching methods and content knowledge."}

On the other hand, unless the trainees are ICT literate, including the technical aspects of ICT in a training programme is still important. For instance, Preston et al. [22] asserted the need for training in specific ICT skills, especially skills in solving technical problems and understanding the basic workings of the technology, and they provide evidence that the breakdown of equipment prevents teachers from using ICT. It is also found that teachers who were ICT beginners were more likely to prefer to learn ICT basics first and then later to be involved in pedagogical training. Moreover, Cunningham et al. [10] in their research on the 'Laptops for Teachers' initiative indicated that the teachers who received a laptop would need to be trained to use it properly, especially with regard to the other ICT tools 
connected to it, such as interactive white board and data projectors, in order to ensure better ICT implementation. Lee [23] argued that older teachers are not expected to have been equipped with ICT basic skills in initial teacher training as ICT had not been introduced to their institutions at that time. Murphy and Greenwood [24] agreed with Lee [23] when they stated that in the past student teachers suffered from a lack of ICT adoption by their institutions and were not encouraged in ICT practice. In order to solve the problem of the lack of effective training, two solutions were suggested. Firstly, any training in ICT must be divided into two phases, the technical skills and the pedagogical skills respectively [25]. Secondly, any training package should not be 'one size fits all'; rather it should be designed to meet its trainees' needs and to provide experiences in using computers [26].

The problem of lack of effective training is reported by many Saudi researchers $[27,28,29,30,12,31]$ and other Arabic researchers [32-34] as a major obstacle to using technology properly in classrooms. Al- Omar [27] clearly summarised the problem of technology in Saudi primary schools, stating that the majority of primary teachers graduated before the introduction of computers in schools; therefore they are computer illiterate. Waiting for another generation of teachers who are computer literate to start using technology in primary schools is impossible. Thus there is a real need for in-service training for teachers in primary schools. Despite the fact that the present study is interested in novice teachers with a maximum of five years' teaching experience, this does not necessarily mean that they are literate regarding using technology and related pedagogies. This is because education colleges in Saudi universities do not pay great attention to training student teachers in using educational technology. Al-Joudi [35] examined computer experience, computer knowledge and computer training needs of Saudi Arabian Teacher Colleges' staff and students in five regions. He also investigated their attitudes toward computers and the human and physical resources available for proper training courses on computers to meet these needs. He found that the majority $(90 \%)$ of student teachers are interested in receiving computer training that is formulated and organised according to their needs. He also emphasised the problem of insufficient training in ICT provided to pre-service teachers in these colleges. Similarly, the findings from Al-Oteawi's [36] study of the perceptions of administrators and teachers, both male and female, toward successful utilisation of ICT in instruction and staff development in Saudi Arabian high schools (secondary schools), showed that teacher training colleges did not provide sufficient training in ICT, especially the basic computer and Internet skills. Al- Jarf [37] recommends that mastering computer and Internet skills should be a preservice prerequisite for teacher graduates at King Saud University, which is one of the best, oldest and biggest universities in Saudi Arabia. The evidence clearly indicates that Saudi pre-service teachers are not being effectively prepared for the Information Age.

In-service teacher training in Saudi Arabia was also reported as ineffective. In his evaluative study of the quality of science teachers' practice in ICT-supported learning and teaching environments in Saudi primary schools that involved 241 teachers and 53 supervisors, Bingimlas [6] identified a number of the obstacles that impede science teachers from using ICT in Saudi primary schools. One of the major obstacles was lack of training and experience or as he calls it "lack of effective professional development" (p. 2). One of the teachers interviewed in Bingimlas's [6] study said that the training courses, which were run by the Training Department in Riyadh, were not as professional as expected since they did not address the pedagogical aspects of employing ICT in the classroom effectively. According to Oyaid [38], although Saudi teachers have access to hardware and software, lack of available training holds the teachers back from using ICT in their teaching. She also claimed that lack of appropriate ICT training and lack of awareness of its benefits in teaching in Saudi Arabia could limit the success of any educational innovations. She suggested, therefore, that teachers' attitudes towards ICT may be changed when proper training is delivered. The analysis of her data collected from interviewing secondary teachers showed that the interviewees expressed their need to receive training on either the pedagogical skills or the technical skills. Regarding the former, as one of Oyaid's [38] interviewees said:

"The most important thing is training in how to use ICT in teaching, because general ICT skills can be obtained easily in a one week training course but the difficult bit is to use it in my teaching. " [38] (p. 113)

Regarding technical skills, Oyaid [38] (p. 113) said:

"Training to use available hardware was also mentioned. Teachers expressed their need to be trained specifically in new equipment introduced in school, such as scanners, printers, digital cameras and so on, and not to assume that teachers with good ICT skills could use other electronic devices without instruction or training."

Alamri's [39] study of globalization and the impact of the Internet on English language teaching in Saudi Arabia showed that Saudi English language teachers need to be trained and supported to use the Internet in their teaching so they become confidents in using new methods, especially if they are used to using traditional methods that depend on text books and prepared materials. She also recommends empowering them to make the most meaningful use of the Internet for teaching purposes. Alghamdi [40] also carried out a study of 202 Arabic Language teachers in Jeddah, Saudi Arabia, to explore to what extent they use ICT and its effectiveness in teaching Arabic Language. One of his major results was that lack of ICT training is a key barrier that impedes Arabic Language teachers from utilising ICT in their instruction in Saudi primary schools.

These pieces of evidence clearly show that the quality of the training programmes in ICT in Saudi Arabia is not as professional as it should be, since they focus on the technical 
skills separately from the pedagogical skills. Moreover, the number of training packages available is not adequate to train all teachers. Therefore, it could be argued that there is an urgent need for a professional training package in ICT that combines technical and pedagogical aspects of technology.

\subsection{Lack of Time}

Lack of time is a universal problem in using technology; it is found wherever using technology is mentioned no matter how developed in the country. For example, in Pelgrum's [11] study to investigate the obstacles to the integration of ICT in education, the results of the survey of twenty-six non-Arabic countries worldwide showed that $54 \%$ of teachers believe that they do not have sufficient time to use technology in the classroom. In a literature review of the barriers that hinder teachers from using ICT, the British Educational Communications and Technology Agency (Becta) [2] reported that teachers lack time to either attend training or prepare technology based teaching materials. More specifically, the respondents reported that they are likely to need longer time to find advice on the Internet, prepare and organise materials, attend sufficient training, practise technology and work on technical issues.

Many studies from different parts of the world have found similar results to Becta's. For instance, in the review by Hew and Brush [41] of the literature of the period from 1995 to Spring 2006 made on the barriers to adopting ICT in education and the strategies to overcome them in both USA and other countries, they found that teachers need a very long time to surf the Internet to find different resources for their projects.

Kula [42] found that the barriers that teachers have in Turkey are very similar to those worldwide. These barriers are shortage in time needed to prepare their teaching resources as well as shortage of time for attending adequate ICT training. Khan et al. [43] reported that Bangladeshi teachers have a heavy workload and thus they lack time that is necessary to prepare technology materials, attend training and plan how to integrate it into their curriculum. In Cyprus, Vrasidas et al. [44] carried out a survey on 10 high schools and 14 primary schools, to explore the challenges and the opportunities that teachers have to deal with when they use ICT. More than half of the teachers $(71.7 \%)$ reported lack of time in the classroom as a key barrier to ICT integration while $60.4 \%$ reported lack of time needed to prepare ICT-based activities as a main barrier. Similarly, in Hong Kong, Wong [45] conducted a study of primary heads and teachers to investigate their perspectives on the implementation of ICT. His data show that teachers could not integrate ICT into their teaching because they lack time for planning and preparing, regardless of whether or not they were willing to use it. On the other hand, one of Becta's reports written by Scrimshaw [46], which was about the enablers that help teachers to make successful use of ICT, suggested allowing sufficient time for teachers to plan and prepare as a key factor that could enable better use of ICT in every day teaching. The report also claimed that teachers need to take enough time to familiarise themselves with the ICT tool and its technical issues; "the more familiar they are with any of our equipment the more they will use it" [46] (p. 11).

In Saudi Arabia, the factor of lack of time also exists. In addition to the lack of time for preparation and training, there is the lack of time in the classroom. In Saudi Arabia, each class lasts for 45 minutes only. Thus, when there is a lot to cover in that period, teachers will be less likely to use technology where they believe it wastes time. For instance, Al-Rashed's [12] study on the current use and needs in technology of teachers in Saudi primary schools found that the majority of teachers taking part in the research emphasised lack of time as a hindrance to both use of computers in classrooms and attendance at training in ICT. He added that teachers unanimously agree that using ICT in teaching would be weak and unsuccessful, due to insufficient time. Al-Alwani [5] found, in his study to determine the current level of ICT use in science education in Yanbu school district in Saudi Arabia, that Saudi science teachers of primary, intermediate and secondary stages were unable to use technology in their teaching due to their workload that left them with insufficient time. Moreover, the findings of Alsulaimani's [47] study of 309 intermediate school teachers, namely, "What impedes Saudi science teachers from using ICT?", indicated that more than $91 \%$ of the participants identified lack of time as the strongest barrier. Furthermore, Aldossry [48] investigated a total of 53 female science teachers from ten intermediate schools in Riyadh City using a questionnaire and conducted four interviews in order to explore their perceptions of integration of ICT in the classroom. She concludes that the teachers suffer from a lack of time that impedes their use of ICT in the classroom. The teachers identify three time factors that affect their use of ICT. Firstly, the short and limited class time where 45 minutes are too short to use technology and achieve the lessons' objectives. Secondly, teachers felt that technology wastes class time. Thirdly, a large number of students, combined with shortage of time led to claims that a teacher may lose control of the class when using technology in these conditions. Alwadaani [31] was interested in the use of educational technology and laboratory teaching aids for mathematics primary teachers in Jazan city, Saudi Arabia. He collected data from 89 mathematics teachers. His analysis revealed that $89 \%$ of the participants indicated that the mathematics curricula are huge and cannot be done in the time-frame that is provided by the MoE. Moreover, $83.8 \%$ of the teachers reported that the packed classes would never encourage them to use technology because they feared they would be likely to lose control of the class. These two factors and others meant that the participants were less likely to use technology in the classroom or to take their students to the mathematics laboratory if one existed. Having a huge number of students was also the most commonly mentioned barrier that hindered teachers of the Holy Quran in secondary schools in Riyadh city, Saudi Arabia, from using educational 
technology, as reported by Alfifi [49]. Al-Khraiji's [50] study shows other forms of challenges of time when using technology in the classroom. She carried out her study to explore computer teachers' perspectives of the obstacles that they confront when using technology in the classroom in Makkah's secondary schools. Her study suggests that despite that fact that the participants are computer teachers, they require more time to [50] (p. 69):

- learn about computer development,

- attend technology training sessions,

- figure out how to integrate technology in the classroom, and

- use technology in the classroom.

\section{Summary and Recommendations}

This paper has reviewed three factors that prevent teachers from using ICT frequently and appropriately for their teaching including lack of access to technology, lack of effective training, and lack of time. The paper has also paid greater attention to these factors in Saudi Arabia.

The Ministry of Education should find permanent solutions for the barriers that disable teachers' use of ICT, especially the ones which are related to education policy such as lack of time and lack of access to technology. It is recommended that the class time is extended and that curricula are reduced so teachers could have sufficient time to fulfil the requirements of each curriculum within the lessons available, making use of ICT. Teachers need to be released from their workload for a reasonable time to attend training without the fear of the accumulation of work when they go back to their schools. This may be achieved by using substitute teachers. It is also recommended that schools to be provided with sufficient, appropriate and up-to-date technologies. It would be vital to create a database of technology media and resources that suit the Saudi curricula and culture. The Ministry must emphasise in-service training as one of its priorities and always make it available for teachers of all stages, including primary teachers. Thus, teachers would be able to cope with the rapid evolution of technology. It is recommended that the technical and the pedagogical skills of using technology always be combined in such training packages, in order to gain the most from the training. The Ministry of Higher Education should pay more attention to preparing student teachers for the technology age. The ICT curricula taught in the teacher preparation institutions and the standards required should be revisited and improved. Basic ICT technical and pedagogical skills should be among the qualifying pre-requisites.

\section{REFERENCES}

[1] N. Alev. Integrating Information and Communications Technology (ICT) into Pre-service Science Teacher
Education: The Challenges of Change in a Turkish Faculty of Education. Doctor of Education Thesis. University of Leicester, 2003.

[2] A. Jones. A review of the research literature on barriers to the uptake of ICT by teachers. British Educational Communications and Technology Agency (Becta). Online available from $\mathrm{http}: / /$ dera.ioe.ac.uk/1603/1/becta_2004_barri erstouptake_litrev.pdf, 2004.

[3] O. Almaghlouth. Saudi Secondary School Science Teachers' Perceptions of the Use of ICT Tools to Support Teaching and Learning. Master Thesis. University of Waikato, 2008.

[4] M. Cox, C. Preston, K. Cox. What factors support or prevent teachers from using ICT in their classrooms? Paper presented at the British Educational Research Association Annual Conference, University of Sussex at Brighton, September 2-5, 1999.

[5] A. Al-Alwani. Barriers to Integrating Information Technology in Saudi Arabia Science Education. Doctoral dissertation, The University of Kansas, Kansas, 2005.

[6] K. A. Bingimlas, Evaluating the Quality of Science Teachers' Practices in ICT-Supported Learning and Teaching Environment in Saudi Primary Schools. PhD thesis, RMIT University, 2010.

[7] P. Foley, X. Alfonso, S. Ghani. The digital divide in a world city: A literature review and recommendations for research and strategy development to address the digital divide in London. IECRC and Citizens Online for the Greater London Authority, LondonConnects and the London Development Agency, 2002.

[8] B. Smerdon, S. Cronen, L., Lanahan, J., Andesron, N., Iannotti, J., Angels. Teachers' tools for the 21st century: A report on teachers' use of technology. National Centre for Education Statistics. Report number: NCES 2000-102, 2000.

[9] S. Mumtaz. Factors affecting teachers' use of information and communications technology: A review of the literature, Technology, Pedagogy and Education, Vol.9, No.3, 319-342, 2000 .

[10] M. Cunningham, K., Kerr, R., McEune, P. Smith, and S. Harris, Laptops for teachers: An evaluation of the first year of the initiative. Becta for the Department for Education and Skills. ICT in Schools Research and Evaluation Series. Report number: 19, 2003.

[11] W. J. Pelgrum. Obstacles to the integration of ICT in education: Results from a worldwide educational assessment, Computer \& Education, Vol.37, No.2, 163-178, 2001.

[12] H. Al-Rashed. Teachers and Information Communication Technology in Saudi Arabia: Current Use and Training Needs, $\mathrm{PhD}$ thesis, The University of Hull, 2002.

[13] M. Al-Showaye. Use of Computer-Based Information Technology and the Internet in Saudi Arabian Intermediate and Secondary Schools, $\mathrm{PhD}$ thesis, University of Manchester, 2002.

[14] M. Al-Saif. An Evaluation of Computers Use Experience in Private Girls Secondary Education in Riyadh City, Teachers Perspective, Master dissertation, King Saud University, 2006.

[15] A. Oyaid. Secondary student's perceptions of Information and Communication technology and their usage of it inside and 
outside of school in Riyadh city, Saudi Arabia', International Journal of Applied Educational Studies, Vol.7, No.1, 27-42, 2010.

[16] E. A. A. Gady. The Reality of the Use of Educational Means and Educational Technology in Teaching English Language in Intermediate Stage: The Perceptions of the Supervisors of the English Language and the Headteachers in Makkah, Master dissertation, Umm Al-Qura University, 2008.

[17] J. Alghamdi. The Reality of Computer in Secondary Education, A Descriptive Analytical Study, Master dissertation, Umm Al-Qura University, 2001.

[18] T. Glennan, A. Melmed. Challenges of creating a nation of technology-enabled schools. In: Pea, R. (ed.) The Jossey-Bass Reader on Technology and Learning. San Francisco, CA: Jossey- Bass, 48-79, 2000.

[19] E. Al Mulhim. Why novice female teachers in Saudi Arabia do not use ICT in their teaching?. In M. Searson \& M. Ochoa (Eds.), Proceedings of Society for Information Technology \& Teacher Education International Conference 2014, 2118-2123, 2014.

[20] J. McCarney. Effective models of staff development in ICT, European Journal of Teachers Education, Vol.27, No.1, 61-72, 2004.

[21] S. Unal, and I. H. Ozturk, Barriers to ITC integration into teachers' classroom practices: Lessons from a case study on social studies teachers in Turkey. World Applied Sciences Journal, Vol.18, No.7, 939-944, 2012.

[22] C., Preston, M. J., Cox, and K. M. J. Cox, Teachers as innovators: An evaluation of the motivation of teachers to use information and communications technologies. Croydon: King's College London and Mirandanet, 2000.

[23] D. Lee. Factors influencing the success of computer skills learning among in-service teachers', British Journal of Educational Technology, Vol.28, No.2, 139-141, 1997.

[24] C. Murphy, L. Greenwood. Effective integration of information and communications technology in teacher education', Journal of Information Technology for Teacher Education, Vol.7, No.3, 413-429, 1998.

[25] R. Snoeyink, P. Ertmer. Thrust into technology: How veteran teachers respond, Journal of Educational Technology Systems, Vol.30, No.1, 85-111, 2001.

[26] W. Veen. The role of beliefs in the use of information technology: Implications for teacher education, or teaching the right thing at the right time, Journal of Information Technology for Teacher Education, Vol.2, No.2, 139-153, 1993.

[27] B. O. Al-Omar. Internet in education and ICT teachers, Journal of Arab Childhood, Vol.0 (April), 12-16, Kuwait, 1999.

[28] I. Al-Sadan. An Investigation Study of the Present Professional Preparation for Teachers in Primary Schools in Saudi Arabia, with Special Reference to Islamic and Arabic Subjects, PhD thesis, University of Hull, 1997.

[29] A. Al-Moosa. The Use of Computers in Education, Riyadh: Al-Shaqra Library, 2000.

[30] I. B. Al-Mohaissin. Introducing Computers into Secondary
School Science Teaching in Saudi Arabia: Teachers' Views, Some Problems and Possible Solutions, $\mathrm{PhD}$ thesis, University of Hull, 1993.

[31] M. R. Y. Alwadaani. The Reality of the Usage of Educational Technology and Laboratory Teaching Aids for Teaching Mathematics in Primary Stage, Master dissertation, Umm Al-Qura University, 2009.

[32] A. Albirini. An Exploration of the Factors Associated with the Attitudes of High School EFL Teachers in Syria toward Information and Communication Technology, Doctoral dissertation, Ohio State University, 2004.

[33] A. Sadik. Factors influencing teachers' attitudes towards personal use and schools use of computers: New evidence from a developing nation, Evaluation Review, Vol.2, No.1, $1-29,2006$

[34] J. A. Al-Ammari. Benefits and Barriers to Implementing Computer Use in Qatar Elementary Schools as Perceived by Female Teachers, An Exploratory Study, Doctoral dissertation, Ohio State University, 2004.

[35] M. Al-Joudi. An Investigation of the Computer Training Needs of the Teachers and Students at Teacher Colleges in Saudi Arabia, PhD thesis, University of Hull, 2000.

[36] S. M. Al-Oteawi. The Perceptions of Administrators and Teachers in Utilizing Information Technology in Instruction, Administrative Work, Technology Planning and Staff Development in Saudi Arabia, $\mathrm{PhD}$ dissertation, Ohio University, 2002.

[37] R. Al-Jarf. Use of SharePoint as a learning management system by KSU faculty, The 5th International Scientific Conference: eLearning and Software for Education, Bucharest, April 2009-2010, 351-356, 2009.

[38] A. Oyaid, Education Policy in Saudi Arabia and its Relation to Secondary School Teachers' ICT Use, Perceptions, and Views of the Future of ICT in Education. PhD thesis, The University of Exeter, 2009.

[39] N. M. Alamri, Impact of Globalisation and the Internet on English Language teaching in Saudi Arabia. Master dissertation, De Montfort University, 2011.

[40] A. Alghamdi. To What Extent Has Information and Communication Technology (ICT) Contributed Arabic Language Teachers in Teaching within Primary Schools in Saudi Arabia?, Master dissertation, Roehampton University, 2011.

[41] K. F. Hew, T. Brush. Integrating technology into K-12 teaching and learning: Current knowledge gaps and recommendations for future research, Educational Technology Research and Development, Vol.55, No.3, 223-252, 2007.

[42] A. Kula. Barriers for ICT Integration, Strategies Developed against Them and Cases in Turkey. Online available from http://www.academia.edu/294212/Barriers_For_ICT_Integra tion_Strategies_Developed_Against_Them_and_and_Cases_ in_Turkey, 2010.

[43] M. S. H. Khan, M. Hasan, C. K. Clement. Barriers to the introduction of ICT into education in developing countries: The example of Bangladesh', International Journal of Instruction, Vol.5, No.2, 61-80, 2012. 
[44] C. Vrasidas, I. Pattis, P. Panaou, M. Antonaki, C. Aravi, L. Avraamidou, K. Theodoriddou, M. Zembylas. Teacher use of ICT: Challenge and opportunities, In: Dirckinck-Holmfeld, L., Hodgson, V., Jones, C., de Laat, M., McConnell, D. and Ryberg, T. (eds.) Proceeding of the 7th International Conference on Networked Learning, 439-445, 2010.

[45] K. P. Wong. The Implementation of ICT in Primary Schools in Hong Kong: Perspectives from School Heads and Teachers, Doctoral thesis, University of Leicester, 2005.

[46] P. Scrimshaw. Enabling Successful Use of ICT. The British Educational Communications and Technology Agency (Becta). Online available from: http://dera.ioe.ac.uk/1604/1/becta_2004_enablingsuccessfulu se_litrev.pdf, 2004.
[47] A. A. Alsulaimani, What impedes Saudi science teachers from using ICT?. Journal of Education and Practice, Vol.3, No.12, 146-155, 2012.

[48] N. Aldossry. Investigation of Saudi Arabia Female Science Teachers' Perceptions of Integration of ICT in the Classroom, Master dissertation, Exeter University, 2011.

[49] A. A. H. Alfifi. The Reality and the Barriers of ICT Usage in Teaching Quran in Secondary Schools in Riyadh City, Master dissertation, Al-Imam Muhammad Ibn Saud Islamic University, 2012.

[50] R. S. Al-Khraiji. Obstacles and Determinates of Teaching Computers in Secondary Schools in Makkah, Saudi Arabia: Teacher Perspectives, Master dissertation, University of Manchester, 2001. 